Lo Bello, Maya J. "Gluck, Mary. 2016. The Invisible Jewish Budapest: Metropolitan Culture at the Fin de Siècle. Madison, WI: University of Wisconsin Press. 251 pp. (Gluck, Mary. 2017. A láthatatlan zsidó Budapest. Budapest: Múlt és Jövő Alapítvány. 224 pp)." Hungarian Cultural Studies. e-Journal of the American Hungarian Educators Association, Volume 10 (2017) DOI: 10.5195/ahea.2017.283

\title{
Gluck, Mary. 2016. The Invisible Jewish Budapest: Metropolitan Culture at the Fin de Siècle. Madison, WI: University of Wisconsin Press. 251 pp. (Gluck, Mary. 2017. A láthatatlan zsidó Budapest. Budapest: Múlt és Jövő Alapítvány. 224 pp).
}

\author{
Reviewed by Maya J. Lo Bello*, Eötvös Loránd University, Budapest
}

Upon reading (and then re-reading) Mary Gluck's impressive examination of the role played by secular Jewish authors, journalists and performers in forming the landscape of popular culture in post-1867 Budapest, I find myself echoing the positive sentiments expressed by this volume's many other reviewers. Since its publication in the United States, The Invisible Jewish Budapest has not only been hailed as a significant addition to scholarly examinations of Jewish contributions to the emergence of modern urban centers, it has also been published by Múlt és Jövő ['Past and Present'] Publishers (trans. Péter Lengyel) and was made available to Hungarian readers at the Budapest Festive Book Week held in June 2017. While the relative speed with which Mary Gluck's work was translated into Hungarian may seem obvious given the fact that The Invisible Jewish Budapest redresses the absence (and hence "invisibility") of Hungary's Jewish population in official narratives of Budapest's history, it is my opinion that the volume's enjoyable prose, fluid translations, relevant illustrations and devotion to recreating the era via a dazzling spectrum of periodicals, newspapers and travelogues has earned it a place among cultural histories of modern Hungary.

An excellent academic work, however, deserves more than mere appreciation: as a researcher of modern Hungarian literature from the fin-de-siècle period, my reading of Mary Gluck's analysis was influenced by the training I have received at Hungarian institutions. Traditionally, Hungarian modernism is connected to the founding of the literary journal Nyugat ['West'] in 1908. While literary historians mostly agree that modernism predated 1908, general opinion still clings to this year as the turning point for the emergence of modern Hungarian culture. Published in 2010 by the Academy of Sciences, the handbook edited by Tibor Gintli, Magyar irodalom, ['Hungarian Literature'] dates this period as "from roughly 1890 to the present" ['kb.1890-töl napjainkig'] and introduces the era with a strong argument that the widespread mythification of Nyugat's role in "ushering in" modernism has obscured the modern literary advancements achieved at the end of the nineteenth century (ed. Gintli: 641). In my experience, the attempts made by Hungarian historians to retrace modernism's beginnings back to the pre-1908 period have generally occurred in reference to a single author, such as Gyula Krúdy, who began his career in 1895, yet also published in Nyugat. (For more information about

*mayatoth@yahoo.com

(cc) $\mathrm{Br}$

ULLS D-Serle
New articles in this journal are licensed under a Creative Commons Attribution 4.0 International License.

This journal is published by the University Library System of the University of Pittsburgh as part of its D-Scribe Digital Publishing Program and is cosponsored by the University of Pittsburgh Press 
Lo Bello, Maya J. "Gluck, Mary. 2016. The Invisible Jewish Budapest: Metropolitan Culture at the Fin de Siècle. Madison, WI: University of Wisconsin Press. 251 pp. (Gluck, Mary. 2017. A láthatatlan zsidó Budapest. Budapest: Múlt és Jövő Alapítvány. 224 pp)." Hungarian Cultural Studies. e-Journal of the American Hungarian Educators Association, Volume 10 (2017) DOI: 10.5195/ahea.2017.283

Gyula Krúdy, see in this issue Zsófia Kalavszky’s examination of Krúdy’s novel, A vörös postakocsi ['The Crimson Coach']: https://doi.org/10.5195/ahea.2017.295). For Hungarian academics, Gluck's reconstruction of how late nineteenth-century newspapers, pulp fiction, jokes, informal urban texts and cabaret songs "created images of the modern city, showing its inhabitants what the urban space looked and felt like, how it should be negotiated and consumed, and how its dangers might be managed and guarded against" (19) provides a clear methodology toward mapping modernism in a more interdisciplinary and comprehensive way.

Gluck's main premise - the invisibility of Jewish Budapest due to the exclusion of Jewish popular culture from the nationalist, mainstream narrative - is based on the argument that "the story of Jewish modernity is best studied not through the celebrated achievements of individuals and elite groups but through the everyday narratives, informal practices, and popular rituals of urban life" (5). While I applaud Gluck's fascinating approach, I cannot help also feeling that Gluck sometimes draws too stark of a contrast between an elite culture that remains silent on the issue of its Jewishness (the author refers to the cases of György Lukács, or Nyugat's editor, Ernő Osvát) and a street culture that openly uses its Jewishness to develop an identity fit for a modern urban setting and culture. As Dávid Szolláth describes in this issue

(https://doi.org/10.5195/ahea.2017.296), anti-Semitic newspapers regularly unmasked members of the cultural elite as Jews, just as Nyugat was regularly attacked for its "un-Hungarian" usage of language, feared for its ability to contaminate "pure" Hungarian with Budapest's infected (i.e., Yiddish-influenced) speech. Inversely, non-Jewish authors could be tarred with the same brush for participating in the era's modern literary movements. As I agree that the issue deserves further investigation, I hesitate to be as definite as Gluck in stating that Jewishness was invisible within the era's high culture and suggest that "hidden" may be a closer description. What, after all, appears invisible to readers today was not only apparent at the time, but also the main means of marking and defining literary output.

Gluck points to the case of Osvát editing all Jewish references out of a short story by Lajos Nagy as an example of the unspoken rules dominating Hungary's "bifurcated cultural system" that demanded authorial adherence to "the unwritten rules for representing Jews in literature" (84-85). As telling as this anecdote may be, one example cannot summarize the attitude of a journal that published literature bi-monthly for nearly four decades. It cannot be denied that Nyugat's authors of Jewish origin seem to remain stubbornly silent on the issue of their background: from 1908 to 1923, for example, it was rare for the Nyugat critic and editor, Miksa Fenyö, to make anything but an oblique reference to his Jewishness. It cannot be forgotten that during this period Nyugat's literary critics demanded that literature be valued for its aesthetic qualities - not for its ability to represent "Hungarianness." Within this framework, the concepts of both "Jewishness" and "Hungarianness" were negated as criteria for measuring a work's literary worth. As the many attacks against modernist literature demonstrated, simply overturning these categories did not make it any easier for an assimilated author to negotiate or appease the demands raised by conservative critics. This stance did, however, contribute toward establishing a critical foundation for judging literary works based on aesthetic merit and the author's ability rather than his or her background.

In spite of Nyugat's attempt to remove the question of origin from literary criticism, the topic of Jewishness was definitely raised by Nyugat contributors, albeit at the late part of the period Gluck discusses, which roughly spans the 1880s to 1906, with a discussion surrounding 
Lo Bello, Maya J. "Gluck, Mary. 2016. The Invisible Jewish Budapest: Metropolitan Culture at the Fin de Siècle. Madison, WI: University of Wisconsin Press. 251 pp. (Gluck, Mary. 2017. A láthatatlan zsidó Budapest. Budapest: Múlt és Jövő Alapítvány. 224 pp).” Hungarian Cultural Studies. e-Journal of the American Hungarian Educators Association, Volume 10 (2017) DOI: 10.5195/ahea.2017.283

the 1920s appearing in the volume's Epilogue. In 1915, Sándor Bródy’s “Jewish” play, Lyon Lea ['Lea Lyon'], inspired the Nyugat critics, Lajos Hatvany and Zoltán Szász, to ponder the possible connection between the drama's unparalleled success, Budapest's largely Jewish theater audience and Lyon Lea's Jewish theme. Dezső Szomory and Ernő Szép were pillars of Nyugat's early aesthetic movement, yet they also introduced modern audiences to narrators who refer to their Jewish identities, flaunt a linguistic mixture of literary Hungarian and grammatically imperfect, urban slang and don the flâneur image Gluck describes so eloquently. Personally, I first encountered the fin-de-siècle orpheum and night-life unveiled by Gluck in Ernő Szép's depiction of pre-World War I Hungary in his novel, Lila ákác ['The Purple Wisteria'] (1920). To mention an example from modernist art, Róbert Berény's painting, Cilinderes önarckép ['SelfPortrait with Top Hat'] (1907), immediately came to my mind when I read Gluck's discussion of modernism's favorite figure, the flâneur traversing urban spaces in a top hat and black suit. Guised as flâneur, Berény's self-portrait depicts the artist as an urban figure while transforming his own features into a savagely grotesque caricature of Jewishness - a Jew trapped in a narrow, stuffy, dark environment possessing only a tiny, distant window onto a bright dreamscape.

By the 1920s, increasingly virulent attacks by the anti-Semitic press forced Miksa Fenyö to draw swords in defense of Nyugat's Jewish authors and thereby emerge from his own, selfimposed silence on the topic. (In his private correspondence, however, Fenyő could be counted on to crack a good Jewish joke, the punchline of which was naturally in German.) Ernő Osvát was Nyugat's reigning editor in 1920, when author Károly Pap began his career in Nyugat with the poem $O$ Erdö! ['O Forest!']. Pap's induction into the journal begins with the lyric plea of a "crazy, poor, anemic Jew" ['bolond szegény ritkavérü zsidó'] longing to leave the city's evils for "my Great-Grandmother" ['Ükanyám'], the forest. Throughout the 1920s and 1930s, Pap would publish in Nyugat some of modern Hungarian literature's most impressive short stories depicting Jewish characters and themes.

I make no claim to being as adept in analyzing late nineteenth-century, Hungarian society as Mary Gluck is in her volume, yet I also suggest further complicating the picture by assessing the literary reception of József Kiss or Tamás Kóbor, authors Gluck mentions for their mid-cult or journalistic works. One of the most recognized poets of his time, Kiss was able to publish widely read works featuring Jewish issues and protagonists such as his ballad, Simon Judit (1874), later made into one of the first Hungarian silent films in 1915. While the Catholic press objected to having a Jewish-themed work represent Hungarian culture via international cinema in 1915 , as far as I am aware Kiss's literary oeuvre did not notably invoke the wrath of either conservative or anti-Semitic critics. Indeed, József Kiss was a member of the literary establishment's acknowledged associations, the Petőfi Társaság [Petőfi Society] and Kisfaludy Társaság [Kisfaludy Society]. While I have not researched Kóbor's earlier prose works, his novel, Ki a gettóból ['Out of the Ghetto'] (1911) remains an important source of information on how Jewish craftsmen and their families were affected by the beginning of industrialization at the end of the nineteenth century. A topic of further investigation would be to examine how these Jewish authors were able to remain openly Jewish while also gaining acceptance into the mainstream literary world.

I do not refer to these few examples to quibble with Gluck's essentially correct assessment of Budapest's bifurcated cultural scene, but rather to suggest that high modernist culture was also developing and utilizing the tools at its disposal to gain entry into mainstream 
Lo Bello, Maya J. "Gluck, Mary. 2016. The Invisible Jewish Budapest: Metropolitan Culture at the Fin de Siècle. Madison, WI: University of Wisconsin Press. 251 pp. (Gluck, Mary. 2017. A láthatatlan zsidó Budapest. Budapest: Múlt és Jövő Alapítvány. 224 pp)." Hungarian Cultural Studies. e-Journal of the American Hungarian Educators Association, Volume 10 (2017) DOI: 10.5195/ahea.2017.283

Hungarian culture while simultaneously searching for its own urban identity. The stakes were high: "going public" as an assimilated author demanding the same rights as a Hungarian writer must have been... indescribable. As Ernő Szép's narrator in Lila ákác tries to express it: “I'm a Jew... and anyone who looks at me can tell it just like that: I'm a Jew. It's like they're looking at a thief they just know nicked something once! And I have to look straight back at those eyes, those accusing, blaming, apologetic eyes. Or whatever you call that look that appears when it's been decided: you're a Jew" ['én zsidó vagyok...és valaki rám néz, és az tudja, hogy én zsidó vagyok. Mintha ránéznék valakire, akiröl tudják, hogy az lopott egyszer! És nekem a szememmel ki kell tartanom azt a vádat vagy ráfogást vagy elnézést vagy mi az, hogy az embert zsidónak veszik'] (Budapest: Szépirodalmi, 1967, 57).

When analyzing modernist Hungarian works, the symptoms and traces of this "anxiety of assimilation" (as Dávid Szolláth calls it in his article in this issue) can only be uncovered by placing the text within the framework of a particular era's political and cultural atmosphereincluding the type and extent of any anti-Semitic rhetoric being employed at the time. In The Invisible Jewish Budapest, it is by recreating the context of the fin-de-siècle era's politically and socially tumultuous Budapest that Mary Gluck adeptly interprets seemingly "meaningless" messages embedded in humor magazines, cabaret acts and Jewish jokes. Readers gain an inkling of what it was like not only to stare straight back at "that look," but to do so with biting humor. Recreating all this, however, requires the other side, be it the anti-Semite politician or the liberal Hungarian nobleman. While the volume's introduction and first two chapters risk duplicating the cultural bifurcation Gluck objects to by demarcating Jewish Budapest too sharply from its environment, Chapters Three ("A Jewish Politician in a Divided Public Space") and Four ("The Jewish Humor Magazine and Collective Self-Parody") provide an ample context of the complex interdependence that defined the "push and pull" of Hungarian and Jewish relations in fin-desiècle Budapest. These two chapters are, in my opinion, brilliantly done. Chapter Five ("The Scandal of the Budapest Orpheum") offers a fascinating glimpse into Budapest's music halls that is sadly hampered - through no fault of the author's - by the scarcity of information on how these skits, songs, etc. were performed on stage.

Chapter Six ("Critical Cross-Dressing and Jewish Bourgeois Identity") attempts to balance out the volume's predominantly male viewpoint by examining how one of the most important critics of the time - who attained fame under the pen name of Ignotus - employed a female "voice" and persona (Mrs. Emma) in a series of "letters to the editor." (Two years after writing this column in the newspaper, A Hét ['The Week'], Ignotus was one of the founding members and editors of Nyugat.) In Chapter One, Jewish women only enter the narrative via journalist Tamás Kóbor's complaints that their participation in coffee-house life corrupts them (30), an opinion frequently voiced in both Jewish and non-Jewish sources from the time. As she resurrects the invisible Jewish Budapest, Gluck obviously struggles in her analysis to keep Jewish women from being even more invisible. The explanation for this overwhelmingly male viewpoint could have been provided by Sander Gilman's gendered explanation of fin-de-siècle attitudes as detailed in his monograph, Franz Kafka, the Jewish Patient: "it is impossible to invoke the concept 'Jew' without immediately invoking concepts of masculinity and pathology. For the Jew at the fin de siècle is the male Jew" (New York: Routledge, 1995, 21). The paucity of public discourse on Jewish women during the fin-de-siècle was partly due to the fact that they were not construed as being as problematic as Jewish men were. Within this social construction, 
Lo Bello, Maya J. "Gluck, Mary. 2016. The Invisible Jewish Budapest: Metropolitan Culture at the Fin de Siècle. Madison, WI: University of Wisconsin Press. 251 pp. (Gluck, Mary. 2017. A láthatatlan zsidó Budapest. Budapest: Múlt és Jövő Alapítvány. 224 pp)." Hungarian Cultural Studies. e-Journal of the American Hungarian Educators Association, Volume 10 (2017) DOI: 10.5195/ahea.2017.283

it is hard to know if Ignotus was responding on some internal level to his milieu's rampant feminization of Jewish men, or only identifying with an exploited group, as Gluck suggests (201). Probably both possibilities are true; the former, in my mind, offers a more plausible explanation for Ignotus's abrupt discontinuation of a successful column. Other than Gluck's discussion of "critical cross-dressing," even brief information on how the bodies and gender roles of Jewish men were branded as feminine would have added incredible depth to the caricature of Mór Wahrmann as a buxom, coquettish bride to Kálmán Tisza's role as erstwhile groom that the author includes yet does not discuss in Chapter Four (117).

The Invisible Jewish Budapest rectifies an astonishing gap in information concerning the popular culture of Budapest's secular Jewish population, an endeavor that will certainly pave the way for more inclusive examinations of modernist culture. Gluck may have opted to study everyday life and popular urban rituals over elite groups and the achievements of individuals, but to me her discussion has revealed the bifurcation that groups and individuals are frequently subjected to in cultural narratives. The question lingering in my mind is to what extent Budapest was bifurcated at the time, and how these invisible boundaries and territories fluctuated throughout the process of cultural exchange. The supreme aesthete, Ernő Szép, supported himself writing cabaret songs. Róbert Berény designed and painted billboard ads. As was mentioned previously, Tamás Kóbor was not just a journalist for the mid-cult $A$ Hét, but also a highly respected novelist. Not only did József Kiss write travelogues and edit $A$ Hét, he also discovered Ernő Osvát, Nyugat's future editor, as well as other members of the Nyugat movement. Now that Mary Gluck has exposed the bricks, I can only wish that her next endeavor proves equally impressive in bridging the distances between Jewish Budapest's seemingly divergent streets and sections. 